\title{
Regional distribution of public-private partnership projects: case of Russia
}

\author{
Evgeny Kuzmin ${ }^{1 *}$, Elza Zinatullina ${ }^{2}$, and Elena Mezentseva ${ }^{1}$ \\ ${ }^{1}$ Institute of Economics of the Ural Branch of Russian Academy of Sciences, Department of Regional \\ Economic Policy and Economic Security, Ekaterinburg, 620014, Russia \\ ${ }^{2}$ Ural State University of Economics, Department of Enterprise Economics, Ekaterinburg, 620014, \\ Russia
}

\begin{abstract}
In Russia, regional differentiation poses a threat to the development sustainability. The infrastructural gap between regions is a fundamental aspect of this differentiation. To explore possible solutions to this problem, we discuss the proactive attitude towards implementation of public-private partnership projects as an option for bridging the infrastructure gap. That is why we explore distribution dynamics and structure in the context of private partnership projects in Russia in 20072020. Based on findings, we concluded the following: first, as for the publicprivate partnership projects completed, their distribution across federal districts in Russia, as well as across economy sectors is uneven. Second, distribution of investments in implementation of public-private partnership projects by federal districts corresponds to quantitative distribution of projects. Third, distribution of investments in implementation of publicprivate partnership projects across sectors coincides with distribution of the projects completed. So, we might conclude that in some regions, publicprivate partnership projects are more capital-intensive and large-scale than in others. This might lead to increased regional differentiation. Overall implementation dynamics of public-private partnership projects in Russia suggests that their capacity is still in low demand.
\end{abstract}

Keywords: public-private partnership, regional differentiation, industry differentiation.

\section{Introduction}

Use Reducing differences in development levels of areas is a priority area for sustainable socio-economic growth. However, the case of modern Russia shows significant regional differentiation, which increase more and more in some locations, preventing from the transition to the sustainability strategy. We believe that strengthening the infrastructure in regions and bridging infrastructure gaps are preventive solutions to this problem. This shows a clear need for the use of the institution of public-private partnership (PPP) within the framework of the idea of integrated economic environment.

\footnotetext{
* Corresponding author: kuzmin.ea@uiec.ru
} 
Public-private partnership is one of the modern mechanisms for attracting private companies to finance the construction, operation, and management of infrastructure facilities. The importance of financing through PPP is due to the high interest of public institutions in creating a favourable environment. Against the background of the complicating external economic situation, the issues of the development of internal infrastructure as the basis of competitiveness are of particular relevance for Russia.

PPP in Russia is a relatively new instrument. At the same time, the practice of using such mechanisms for the implementation of projects in creating and updating socially significant infrastructure is becoming more common [1]. The overwhelming majority of Russian regions already use the mechanism of concession agreements for the creation or reconstruction of infrastructure facilities. However, at the same time, only 10 regions (12\%) have concluded more than 100 agreements (including municipal concessions). Over the past five years, there has been a significant reduction in implemented PPP projects in Russia, so in 2020, compared to 2016, the number of implemented PPP projects decreased by 9 times, the volume of budget investments in PPP projects decreased by 44\%. In part, the sharp decline in indicators in 2020 can be explained by the COVID-19 pandemic, but the overall trend of previous years is negative. This indicates the undisclosed potential of the PPP mechanism in Russia [2].

Despite the obvious benefits of using PPP for economic development, the share of investments in infrastructure under the concluded concession agreements in Russia does not exceed $2 \%$ of GDP per year. This is significantly lower than in the UK $-6.6 \%$ of GDP, in Australia and New Zealand $-6.9 \%$ of GDP, in Canada $-8.1 \%$ of GDP [2]. Arguably, infrastructure management remains a barrier to achieving sustainable development goals [35].

Therefore, the research is aimed at statements of trends in regional distribution of PPP projects in Russia. For this, the following tasks were set: to conduct a statistical analysis of the dynamics of implemented PPP projects in 2007-2020 by the federal districts of Russia and sectors of the economy; identify structural differences in distribution of PPP projects.

\section{Literature Review}

An active development of the practice of implementing projects using PPP mechanisms in recent years has attracted an increasing number of researchers. Yescombe [6] offers a unique comprehensive description of the processes, participants, and established practices of publicprivate partnership, and speaks in detail about the main financial aspects of the implementation of PPP projects. The tasks that are solved using PPP can be summarized as follows [7]: PPPs allow the authorities to focus on the main functional area while the solution of infrastructure issues is delegated to private companies; PPPs contribute to improving the management of state assets (a "life cycle" approach is used in the form of long-term contracts), etc.

The Russian specificity in the light of world practice is considered in [8], where the forms, types, and legal regimes of PPPs are specified and their formation features are analyzed. An important aspect for Russia and many developing economies is the problem of abuse of power. Goloborodko et al. [8] assess the legal, economic, and managerial risks in the implementation of PPP projects.

Many researchers note a lack of trust between business and government [9]. This occurs since companies in Russia are not interested in a long-term cooperation. A low time horizon of their operation [10] does not create incentives for long-term investments and innovations [11]. This could be neutralized, according to [9], by the acceptance of the role of a guarantor by the state. A similar opinion was expressed by [12]. Another internal PPP driver specific to Russia is the need to create "growth points" through PPP for regional development [13, 14]. 
The debate about what factors underlie the development of PPP is generally homogeneous. Kazaryan [15], among the factors influencing the development of PPP, notes institutional (reflecting the formation of the regulatory framework governing the development of PPP), competence (reflecting the presence of the necessary managerial competencies among public and private sector employees), socio-economic (reflecting the investment attractiveness of regions for the inflow of investments). In addition to these factors, the presence of risks that affect the implementation of PPPs, as well as forms of project financing, are also highlighted $[16,17]$. Risks affecting the implementation of PPP projects include the risks of planning them, financial risks, including interest rates and inflation, risks of operating the created infrastructure, as well as risks related to the demand for the facilities of the created infrastructure. Hence, one can conclude that the implementation of PPP projects is significantly influenced by financial determinants, including the change in the interest rate on loans, the level of tax burden, the inflation rate, the level of state budget expenditures to GDP [18, 19]. The investment component of PPP projects has an impact on regional economic development. Stable correlations are observed for investment in fixed assets per capita and GRP per capita [20].

\section{Results and Discussion}

The active development of PPP in Russia was observed in the period from 2010 to 2016. Subsequently, the number of projects has steadily decreased - from a peak of 1,270 projects in 2016 to 116 in 2020 , more than 10 times.

The distribution of completed PPP projects across federal districts in Russia is uneven. During 2007-2020, the largest number of implemented PPP projects was observed in the Southern Federal District (3723, or 51\%), the Central Federal District (748, or 10\%), and the Volga Federal District (954, or 13\%). The dynamics of the implementation of PPP projects is presented in Table 1.

Table 1. Dynamics of the implementation of PPP projects in the federal districts of Russia in 2007-2020.

\begin{tabular}{|l|l|l|l|l|l|l|l|l|}
\hline \multirow{2}{*}{ Year } & \multicolumn{7}{|c|}{ Federal district } \\
\cline { 2 - 9 } & SiFD & FFD & NWFD & SFD & CFD & NCFD & UFD & VFD \\
\hline 2007 & 3 & 0 & 1 & 7 & 0 & 0 & 0 & 3 \\
\hline 2008 & 1 & 0 & 0 & 10 & 3 & 0 & 3 & 3 \\
\hline 2009 & 1 & 4 & 4 & 20 & 4 & 0 & 4 & 3 \\
\hline 2010 & 5 & 4 & 2 & 57 & 7 & 0 & 3 & 26 \\
\hline 2011 & 16 & 5 & 4 & 63 & 10 & 0 & 12 & 10 \\
\hline 2012 & 11 & 7 & 4 & 75 & 15 & 2 & 2 & 26 \\
\hline 2013 & 20 & 14 & 9 & 143 & 42 & 1 & 16 & 20 \\
\hline 2014 & 40 & 41 & 15 & 292 & 25 & 16 & 16 & 112 \\
\hline 2015 & 114 & 81 & 33 & 576 & 137 & 3 & 56 & 142 \\
\hline 2016 & 164 & 192 & 59 & 1175 & 322 & 17 & 103 & 261 \\
\hline 2017 & 98 & 122 & 30 & 654 & 99 & 14 & 89 & 190 \\
\hline 2018 & 77 & 36 & 68 & 403 & 39 & 9 & 58 & 99 \\
\hline 2019 & 31 & 20 & 20 & 179 & 26 & 5 & 17 & 46 \\
\hline 2020 & 3 & 8 & 9 & 69 & 19 & 3 & 7 & 13 \\
\hline
\end{tabular}

Source: [21].

Note: SiFD - Siberian Federal District; FFD - Far East Federal District; NWFD - North-West Federal District; SFD - Southern Federal District; CFD - Central Federal District; NCFD - North Caucasian Federal District; UFD - Ural Federal District; VFD - Volga Federal District. 
Similar trends can be traced in the distribution of investments for PPP projects in the regions. The largest share of investments falls on the South Federal District (149.16 billion rubles, or 52\%). The Volga Federal District ranks second (30.92 billion rubles, or 11\%). The third place is occupied by the Ural (26.39 billion rubles, or 9\%) and the Central Federal Districts (25.41 billion rubles, or 9\%). There is the minimal number of implemented PPP projects in the North Caucasian Federal District. In 2007-2020, there was the largest share of implemented PPP projects in the Southern Federal District.

In terms of quantities of projects, the Rostov Region, Volgograd Region, and Krasnodar Territory were leaders. The North-West Federal District has a low level of PPP development. For instance, in 2020, 1 project was implemented in Saint Petersburg, 2 projects in the Arkhangelsk Region, 4 projects in the Leningrad Region, and 1 project in the Pskov Region. In 2020, in the Novgorod Region, Komi Republic, and Republic of Karelia, no PPP projects were implemented.

This means that not all regions are equally attractive to investors.

Budget investments in Russia for infrastructure development in 2019 amounted to about 2 trillion rubles. In relation to GDP, the volume of budget investments increased by only 0.1 percentage points to $1.8 \%$ at the end of 2019. In 2020, the volume of budget investments directly invested in PPP projects amounted to 327.6 billion rubles. In total for the period of 2007-2018, the volume of budget investments in PPP projects increased from 532 billion rubles up to 851.1 billion rubles, or $60.0 \%$. The volume of investments per PPP project in 2007 amounted to 44.3 billion rubles, and in 2020 it decreased to 2.8 billion rubles (Figure 1). Consequently, PPP projects have become less ambitious over the past 13 years. Low indicators are largely due to the absence of a long-term PPP development plan and clear conditions for the implementation of particular PPP projects.

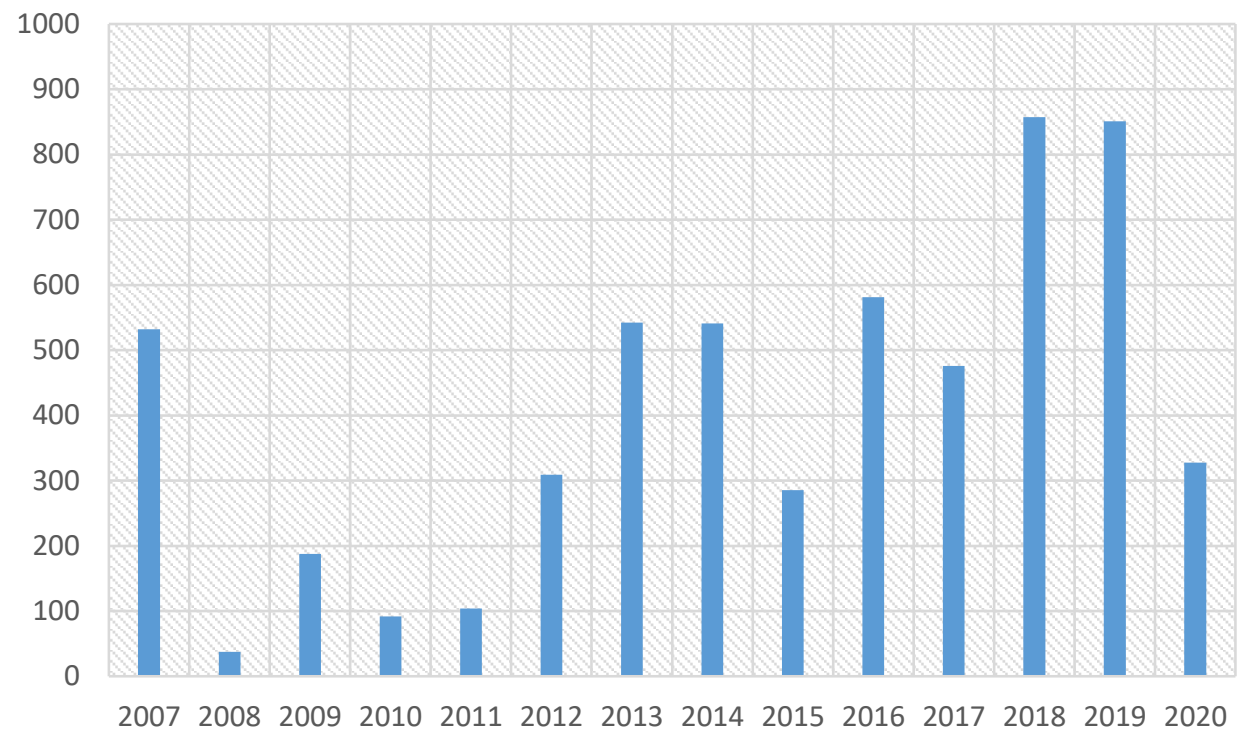

Figure 1. Dynamics of budgetary investments in PPP projects, billion roubles.

Source: [21]

Analysis of this situation allows conclusions as follows:

In 2007-2020, first, distribution of investments in implementation of PPP projects by federal districts corresponds to quantitative distribution of the projects completed. The North 
Caucasian Federal District (RUB4.65 billion or 2\%) and Northwestern Federal District (RUB12.49 billion or 4\%) had the smallest shares in terms of investments in PPP projects.

Second, distribution of investments in PPP projects as well as numbers of PPP projects in federal districts are uneven. For instance, in 2020, the North Caucasian Federal District attracted RUB0.09 billion of budget investments with PPP, whereas in the Ural Federal District, this figure was 19.3 times more. There is the similar difference between the Volga Federal District and Southern Federal District. That is, in some regions, PPP projects are more capital-intensive and large-scale than in others.

In the sectoral context, PPP projects are also not equally attractive to investors. In 2020, 7 PPP projects were implemented in the field of transport, while in the field of agricultural infrastructure they amounted 9.9 times more. The dynamics of the number of PPP projects by sectors are presented in Table 2 .

Table 2. Dynamics of the number of PPP projects by sectors of the economy in Russia in 2007-2020.

\begin{tabular}{|l|l|l|l|l|l|l|l|l|}
\hline \multirow{2}{*}{ Year } & \multicolumn{9}{|c|}{$\begin{array}{l}\text { Sector } \\
\text { sphere }\end{array}$} & Transport & Agriculture & $\begin{array}{l}\text { Defence and } \\
\text { security }\end{array}$ & $\begin{array}{l}\text { House } \\
\text { building }\end{array}$ & Redevelopment & ICT & Manufacturing \\
\hline 2007 & 1 & 0 & 10 & 0 & 7 & 0 & 0 & 0 \\
\hline 2008 & 6 & 0 & 20 & 0 & 10 & 0 & 0 & 0 \\
\hline 2009 & 5 & 1 & 57 & 0 & 20 & 1 & 0 & 0 \\
\hline 2010 & 14 & 3 & 75 & 0 & 57 & 0 & 1 & 0 \\
\hline 2011 & 19 & 4 & 63 & 0 & 63 & 1 & 1 & 2 \\
\hline 2012 & 12 & 2 & 292 & 0 & 75 & 2 & 1 & 1 \\
\hline 2013 & 32 & 1 & 143 & 0 & 143 & 4 & 0 & 0 \\
\hline 2014 & 44 & 4 & 292 & 0 & 292 & 7 & 2 & 0 \\
\hline 2015 & 79 & 10 & 576 & 1 & 576 & 10 & 7 & 5 \\
\hline 2016 & 54 & 7 & 1175 & 0 & 1175 & 16 & 2 & 11 \\
\hline 2017 & 89 & 11 & 654 & 0 & 654 & 26 & 4 & 18 \\
\hline 2018 & 69 & 10 & 403 & 0 & 403 & 18 & 4 & 22 \\
\hline 2019 & 45 & 11 & 179 & 0 & 179 & 14 & 2 & 4 \\
\hline 2020 & 24 & 7 & 69 & 0 & 69 & 7 & 2 & 1 \\
\hline
\end{tabular}

Source: [21]

In the number of PPP projects by sectors, the largest share in 2007-2020 was taken by the projects aimed at modernizing agricultural infrastructure $(4008$, or $47 \%)$, as well as the projects in the field of housing and communal infrastructure (3723, or $44 \%)$. The smallest shares of PPP projects were observed in the field of industrial infrastructure, defense, and security.

Volume distribution of investments in implementation of PPP projects by sectors is visualized in Figure 2. 


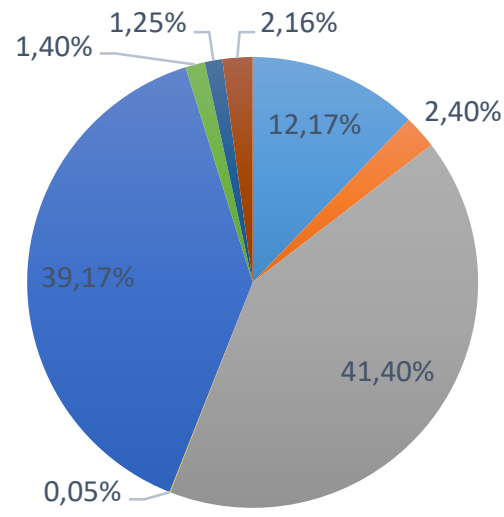

- Social infrastructure

- Transport infrastructure

- Agricultural infrastructure

National defence and infrastructure

- Residential development and infrastructure

Environment improvement

- IT infrastructure

Industrial infrastructure

Figure 2. Distribution of total volume of investments in implementation of PPP projects in Russia by sectors in $2007-2020, \%$.

Source: [21]

Sectoral distribution of investments in implementation of PPP projects coincides with distribution of the projects completed. Investments in the agricultural infrastructure come first (RUB157.64 billion or 41\%). Investments in residential development and communal infrastructure come second (RUB149.16 billion or 39\%). Investments in social infrastructure come third (RUB46.33 billion or 12\%). Finally, investments in national defence and security, investments in IT infrastructure have the smallest shares.

\section{Conclusion}

The research findings are the key trends identified in development of public-private partnerships in Russia. The number of implemented PPP projects has been steadily decreasing since 2016 , from a peak of 1,270 projects to 116 in 2020 . Over the past 13 years, the projects have become smaller in scale; the volume of investments per one PPP project in 2007 was 44.3 billion rubles, and in 2020, it decreased to 2.8 billion rubles. Low indicators are largely due to the absence of a long-term PPP development plan and clear conditions for the implementation of particular PPP projects. The distribution of PPP projects by sectors and regions is uneven. We might conclude that the capacity of the PPP as an institute in Russia is still in low demand.

Within this subject, we believe that the evaluation of an impact that macroeconomic indicators in Russia and across regions make on attractiveness of implementation of PPP projects is a promising for further research. This would make it possible to reveal determinants in regional differentiation, as well as in the gap between socio-economic living standards of the population.

Acknowledgments: The study was funded by the Russian Foundation for Basic Research (RFBR), project No. 19-010-00994.

\section{References}

1. E.I. Khubuluri, N.A. Bagrova, Science and Education: Business and Economy; Entrepreneurship; Law and Governance 1(104), 123-127 (2019) 
2. Ministry of Economic Development of the Russian Federation. Information and analytical review on the development of public-private partnerships in the Russian Federation (Moscow, 2020). Retrieved from https://clck.ru/MNiks

3. Z. Cheng, H. Wang, W. Xiong et al., Environment, Development and Sustainability 23, 1043-1063 (2021)

4. S. Derrible, MRS Energy \& Sustainability 5, 13 (2018)

5. G. Di Liddo, A. Rubino, E. Somma, Journal of Industrial and Business Economics 46, 523-580 (2019)

6. E.R. Yescombe, Public-private partnership: Principles of policy and finance (Alpina Publisher, Moscow, 2015)

7. O.A. Kozhurina, Rostov Scientific Journal 2, 167-174 (2019)

8. A.Yu. Goloborodko, Ya.V. Kozhenko, P.V. Pashkovsky, Public private partnership (Omega Science, Ufa, 2017).

9. A.A. Pankratov, Public-Private partnership in modern practice: Basic theoretical and practical problems (Ankil, Moscow, 2010)

10. E.A. Kuzmin, Data in Brief 16, 850-864 (2018)

11. V.Y. Chernova, V.S. Starostin, E.A. Degtereva, V.I. Andronova, Entrepreneurship and Sustainability Issues 7(1), 540-552 (2019)

12. A.A. Firsova, RISC: Resources, Information, Supply, Competition 2, 563-566 (2011)

13. A.A. Alpatov, A.V. Pushkin, R.M. Dzhaparidze, Public-Private partnership: Implementation mechanisms (Alpina Publisher, Moscow, 2010)

14. E. Litau, Entrepreneurship and economic growth: A look from the perspective of cognitive economics. In ICEME 2018: Proceedings of the $20189^{\text {th }}$ International Conference on E-business, Management, and Economics (2018)

15. M.A. Kazaryan, Economic Sciences 1, 68-74 (2017)

16. E.N. Sidorova, D.A. Tatarkin, Economy of Region 2(22), 95-103 (2010)

17. M.Yu. Sokolov, S.V. Maslova, Bulletin of Saint Petersburg University. Management 4, 100-124 (2013)

18. X. Han, J. Su, J.P. Thia, Economic Change and Restructuring, (2020)

19. E.C. Wang, E. Alvi, Eurasian Economic Review 1, 3-28 (2011)

20. T.M. Barbysheva, Authorities and Governance in the East of Russia 4(93), 133-145 (2020)

21. Rosinfra, Market for PPP projects in Russia (2021). Retrieved from https://rosinfra.ru/digest/market 